Abstracta Iranica Abstracta Iranica

Revue bibliographique pour le domaine irano-aryen

Volume 37-38-39 | 2018

Comptes rendus des publications de 2014-2016

\title{
Yann Richard (éd./comm.). Regards français sur le coup d'État de 1921 en Perse. Journaux personnels de Georges Ducrocq et Hélène Hoppenot
}

\section{Rédaction}

\section{OpenEdition}

\section{Journals}

Édition électronique

URL : http://journals.openedition.org/abstractairanica/46133

DOI : 10.4000/abstractairanica.46133

ISBN : 1961-960X

ISSN : 1961-960X

Éditeur :

CNRS (UMR 7528 Mondes iraniens et indiens), Éditions de l'IFRI

\section{Référence électronique}

Rédaction, «Yann Richard (éd./comm.). Regards français sur le coup d'État de 1921 en Perse. Journaux personnels de Georges Ducrocq et Hélène Hoppenot », Abstracta Iranica [En ligne], Volume 37-38-39 | 2018, document 1, mis en ligne le 30 décembre 2018, consulté le 28 septembre 2020. URL : http:// journals.openedition.org/abstractairanica/46133; DOI : https://doi.org/10.4000/abstractairanica. 46133

Ce document a été généré automatiquement le 28 septembre 2020.

Tous droits réservés 


\title{
Yann Richard (éd./comm.). Regards français sur le coup d'État de 1921 en Perse. Journaux personnels de Georges Ducrocq et Hélène Hoppenot
}

\author{
Rédaction
}

\section{RÉFÉRENCE}

Yann Richard (éd./comm.). Regards français sur le coup d'État de 1921 en Perse. Journaux personnels de Georges Ducrocq et Hélène Hoppenot. Leiden-Boston : Brill, 2015, 699 p., répertoire prosopographique, notices biographiques, bibliographie, chronologie, index général, index des noms en persan, résumé en anglais. Co-publié avec l'Institut français de Recherche en Iran (IFRI). (Iran Studies, 13 ; Bibliothèque iranienne, 78). ISBN

978-90-04-28367-1

1 Dans cette contribution historiographique majeure Yann Richard livre des documents historiques consacrés à un événement aux conséquences décisives pour l'histoire iranienne contemporaine : le coup d'État du 21-22 février 1921 qui porta au pouvoir Reżā Khān/Shāh, le fondateur de la dynastie des Pahlavi (1925-1979). Après avoir présenté l'événement, puis exposé les difficultés méthodologiques pour traiter de façon critique les récits d'histoire officielle et les témoignages externes de différente nature, il reprend l'analyse des sources disponibles: la documentation en persan, rare, mais aussi la documentation provenant des sources diplomatiques étrangères. L'auteur met surtout en valeur les sources françaises, peu exploitées jusque-là, et pourtant capitales pour l'étude de la période comme cela est le cas des journaux personnels de deux témoins oculaires des événements de 1921, publiés " en parallèle » dans le présent ouvrage. Cette publication permet d'apporter des compléments d'information et des 
précisions importantes (par exemple en ce qui concerne la chronologie des événements de la nuit du coup d'État) sur une période clé de l'histoire récente de l'Iran.

2 Un compte-rendu critique détaillé est paru dans Studia Iranica 45 (2016) par Jean Calmard.

\section{AUTEURS}

\section{RÉDACTION}

Direction et secrétariat d'Abstracta Iranica 